\title{
EVIDENCE FOR THE OCCURRENCE OF THE INDO-PACIFIC STONEFISH, SYNANCEIA VERRUCOSA (ACTINOPTERYGII: SCORPAENIFORMES: SYNANCEIIDAE), IN THE MEDITERRANEAN SEA
}

\author{
Dor EDELIST ${ }^{1 *}$, Ehud SPANIER ${ }^{1}$, and Daniel GOLANI ${ }^{2}$ \\ ${ }^{1}$ Department of Maritime Civilizations and the Leon Recanati Institute for Maritime Studies, The Leon H. Chaney \\ School for Marine Sciences, Faculty of Natural Sciences, University of Haifa, Mount Carmel,
} Haifa, Israel 31905, Israel

${ }^{2}$ Department of Evolution, Systematics and Ecology, The Hebrew University of Jerusalem, 91904 Jerusalem, Israel

Edelist D., Spanier E., Golani D. 2011. Evidence for the occurrence of the Indo-Pacific stonefish, Synanceia verrucosa (Actinopterygii: Scorpaeniformes: Synanceiidae), in the Mediterranean Sea. Acta Ichthyol. Piscat. 41 (2): 129-131.

\begin{abstract}
The stonefish, Synanceia verrucosa Bloch et Schneider, 1801, was recorded for the first time in the Mediterranean. The fish was caught by trammel net, at a depth of $3 \mathrm{~m}$, recorded on video and then released. Its occurrence is presumed to be due to either Lessepsian migration or as an escapee from aquaria.
\end{abstract}

Keywords: Synanceia verrucosa, Stonefish, Mediterranean, Lessepsian migration

The rate of influx of Red Sea fishes into the Mediterranean via the Suez Canal (termed "Lessepsian migration") has accelerated during the first decade of the 21 st century (e.g., Rilov and Galil 2009, Golani 2010). Salameh et al. (2011) enumerate 80 such species. The present publication raises the total number to 81 .

On 18 April 2010, a ca. $30 \mathrm{~cm}$ total length (TL) specimen of stonefish, Synanceia verrucosa Bloch et Schneider, 1801, was caught in the Mediterranean coast of Israel (Figs. 1 and 2) by a trammel net set for crabs at a depth of $3 \mathrm{~m}$, in the vicinity of Palmakhim (lat $31^{\circ} 56.36^{\prime}$ $\mathrm{N}$, long $34^{\circ} 42.16^{\prime} \mathrm{E}$ ). The specimen was kept alive in a bucket and video recorded in 2 videos for almost 2 minutes, before it was released alive to the sea. The standard resolution of the video recording allowed identification of the fish to a high level of certainty. The videos were uploaded as an electronic supplement to FishBase (Froese and Pauly 2011) and can be viewed online at http://www.youtube.com/watch? $\mathrm{v}=\mathrm{y} 4 \mathrm{xcMp} 4 \mathrm{rN} 1 \mathrm{Y}$ and http://www.youtube.com/watch?v=Zf_QgNmXvpA.

Description of the Mediterranean specimen based on the video. Body stocky almost globe-like with broad dorsally flattened head, eye slightly elevated, separated by wide shallow depression. Shallow pit behind eye. Mouth half circle and open dorsally. Thirteen dorsal spines nearly equal in length and covered by skin. Round caudal fin. Very wide, fan-like, pectoral fin with 19 fleshy rays. Colour: light tan to beige.
Ecology. Two species of the genus Synanceia occur in the Red Sea (Golani and Bogorodsky 2010). Synanceia verrucosa Bloch et Schneider, 1801 and Synanceia nana Eschmeyer et Rama Rao, 1973. S. verrucosa can be distin-

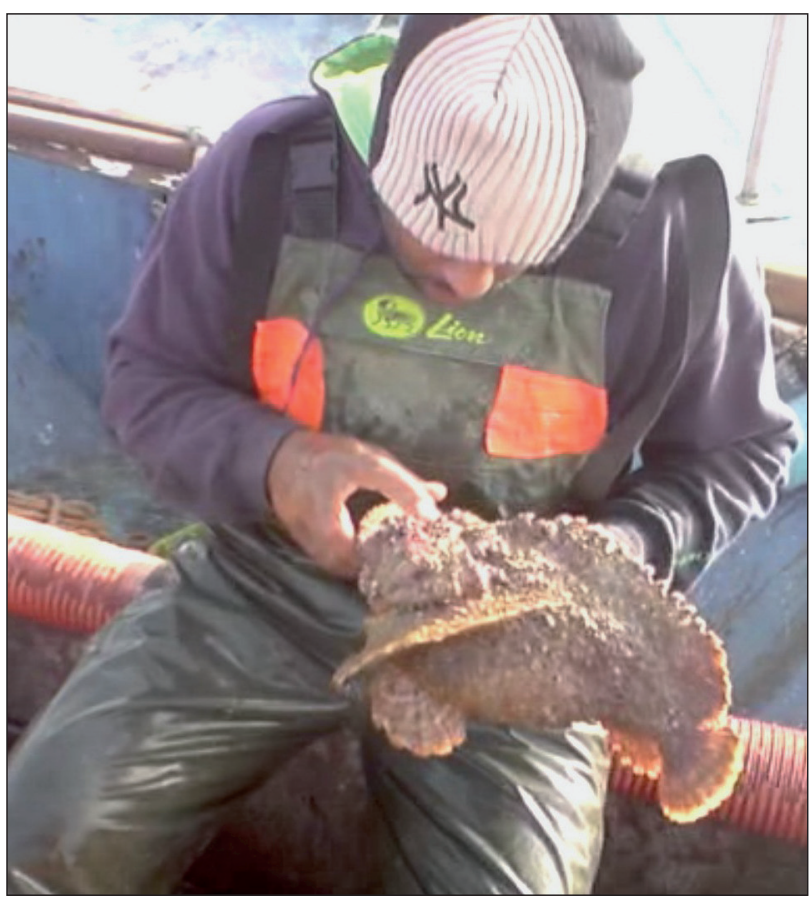

Fig. 1. Lateral view of the Mediterranean specimen of Synanceia verrucosa

\footnotetext{
* Correspondence: Dr Dor Edelist, Department of Maritime Civilizations and the Leon Recanati Institute for Maritime Studies, The Leon H. Chaney School for Marine Sciences, Faculty of Natural Sciences, University of Haifa, Mount Carmel, Haifa, Israel 31905, Israel, phone: +972-4-6249452, fax: +972-4-6240493, e-mail: blackreefs@gmail.com (DE),spanier@research.ac.il (ES),dgolani@cc.huji.ac.il (DG)
} 


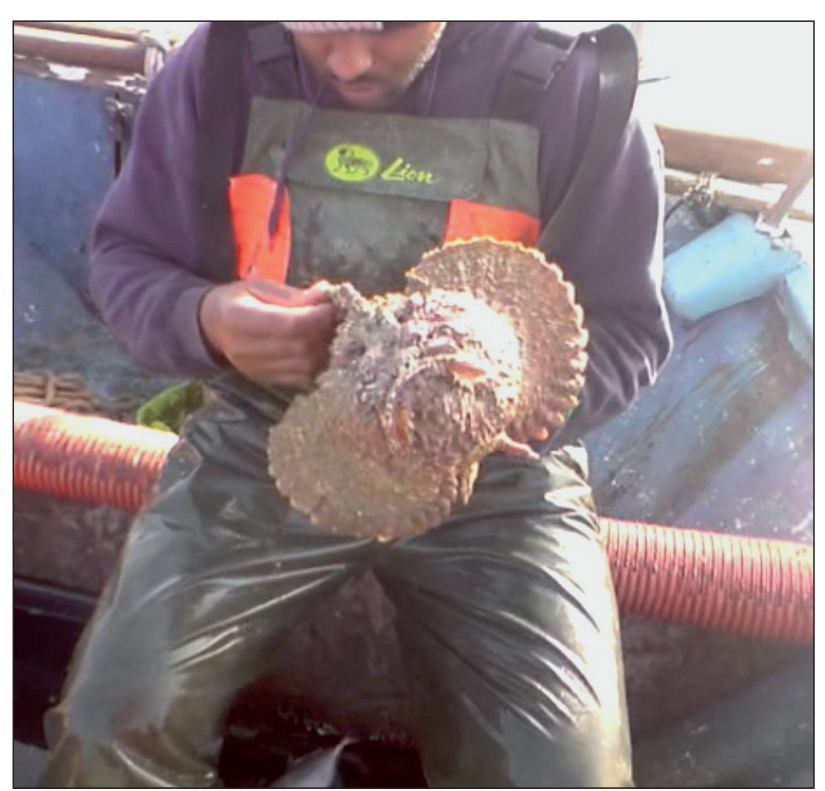

Fig. 2. Frontal view of the Mediterranean specimen of Synanceia verrucosa

guished from S. nana by having 18-19 pectoral rays and 13 dorsal spines versus $14-15$ and 14 , in the latter species. In addition, in $S$. verrucosa there is a distinct lack of dark margins of the pectoral, pelvic and caudal fins that characterize S. nana (see Eschmeyer and Rama Rao 1973, Lieske and Myers 2004). Furthermore, S. nana never exceeds $135 \mathrm{~mm}$ TL while $S$. verrucosa reaches a maximum length of $400 \mathrm{~mm}$ (Poss 1999). Synanceia verrucosa has a wide Indo-Pacific distribution. It is considered one of the most venomous fish in the sea, with fatalities reported in literature (Halstead 1970, Eschmeyer and Rama Rao 1973, Garnier et al. 1995, Spanier 2000, Ngo et al. 2009). It feeds mainly on small and medium-sized fish and invertebrates (Poss 1999). Its source habitat is either sand or rubble areas near reefs or rocky outcrops (Fischer et al. 1990), which can also be found in the shallow Mediterranean coast. Golani (2010) stated that schooling species with high mobility have an advantage over territorial solitary species in colonizing new areas. This is indeed the case concerning Lessepsian fish migrants; with the exception of a few territorial species (namely, Hippocampus fuscus Rüppell, 1838 and Stephanolepis diaspros Fraser-Brunner, 1940) solitary territorial migrants like $S$. verrucosa have only been recorded in the Mediterranean by either a single record or by a very small number of individuals.

Introduction vector. The most probable source of $S$. verrucosa introduction into the Mediterranean is its invasion by pelagic larvae (Debelius 1998). Nevertheless, despite the sluggish movement of adult S. verrucosa (e.g., Grobecker 1983), the possibility of adults swimming along the bottom of the canal should not be ruled out. It is also possible that it reached its new region as an escapee or release from aquaria but to the best of our knowledge this fish is not part of the aquarium trade in Israel. The extremely venomous nature of $S$. verrucosa mandates that a special attention be given to any further observations and that the public is informed on its presence in the Mediterranean.

\section{ACKNOWLEDGEMENTS}

The authors wish to thank Mr. Mohammad Zinb for providing the information and video, as well as Mr. Steve Breitstein for still captures from the video.

\section{REFERENCES}

Debelius H. 1998. Red Sea reef guide-Egypt, Israel, Jordan, Sudan, Saudi Arabia, Yemen, Arabian Peninsula (Oman, UAE, Dahrain). IKAN-Unterwasserarchiv, Frankfurt, Germany.

Eschmeyer W.N., Rama-Rao K.V. 1973. Two new stonefishes (Pisces, Scorpaenidae) from the Indo-west Pacific, with a synopsis of the subfamily Synanceiidae. Proceedings of the California Academy of Sciences 39 (18): 337-382.

Fischer W., Sousa I., Silva C., De Freitas A., Poutiers J.M., Schneider W., Borges T.C., Féral J.P., Massinga A. 1990. Fichas FAO de identificaçao de espécies para actividades de pesca. Guía de campo das espécies comerciais marinhas e de águas salobras de Moçambique. FAO, Roma.

Froese R., Pauly D. (eds.) 2011. FishBase. (version 06/2011) http://www.fishbase.org.

Garnier P., Goudey-Perrière F., Breton P., Dewulf C., Petek F., Perrière C. 1995. Enzymatic properties of the stonefish (Synanceia verrucosa Bloch and Schneider, 1801) venom and purification of a lethal, hypotensive and cytolytic factor. Toxicon 33 (2): 143-155. DOI: 10.1016/0041-0101(94)00151-W.

Golani D. 2010. Colonization of the Mediterranean by Red Sea fishes via the Suez Canal-Lessepsian migration. Pp. 145-188. In: Golani D., Appelbaum Golani B. (eds.) Fish invasions of the Mediterranean-Change and renewal. Pensoft, Sofia.

Golani D., Bogorodsky S.V. 2010. The fishes of the Red Seareappraisal and updated checklist. Zootaxa 2010 (2463): $1-135$.

Grobecker D.B. 1983. The 'lie-in-wait' feeding mode of a cryptic teleost, Synanceia verrucosa. Environmental Biology of Fishes 8 (3-4): 191-202. DOI: 10.1007/BF00001085.

Halstead B.W. 1970 Poisonous and venomous marine animals of the world. 3rd edn. United States Government Printing Office, Washington DC, USA.

Lieske E., Myers R.F. 2004. Coral reef guide; Red Sea to Gulf of Aden, South Oman. Harper Collins, London.

Ngo S.Y.A., Ong S.H.J., Ponampalam R. 2009. Stonefish envenomation presenting to a Singapore hospital. Singapore Medical Journal 50 (5): 506-509.

Poss S.G. 1999. Scorpaenidae, scorpionfishes (also, lionfishes, rockfishes, stingfishes, stonefishes and waspfishes. Pp. 2291-2352. In: Carpenter K.E., Niem V. (eds.) FAO species identification guide for fishery purposes. Vol. 4. Bony fishes, part 2 (Mugilidae to Carangidae). FAO, Rome.

Rilov G., Galil B. 2009. Marine bioinvasions in the Mediterranean Sea - history, distribution and ecology. Biological invasions in marine ecosystems: Ecological Studies 204 (6): 549-575. DOI: $10.1007 / 978-3-540-79236-9 \_31$. 
Salameh P., Sonin O., Edelist D., Golani D. 2011. First record of the Red Sea orangeface butterflyfish Chaetodon larvatus Cuvier, 1831 in the Mediterranean. Aquatic Invasions 6 (1): 53-56. DOI: 10.3391/AI.2011.6.S1.012.

Spanier E. 2000. Baalei Haim Mesukanim Laadam Bemeymey Hahopoim shel Israel. [Dangerous marine animals in the coastal waters of Israel.] Pp. 193-216. In: Adler E., Fine M.,
Baum D. (eds.) Yam Vehopim - Maamarim. [Sea and coasts — articles 2000.] Department of Sea and Coasts, Israel Ministry for Environmental Quality. [In Hebrew.]

Received: 18 July 2010

Accepted: 4 January 2011

Published electronically: 30 June 2011 